\title{
Why more West than East German firms export
}

Wagner, Joachim

\author{
Publication date: \\ 2007
}

\section{Document Version}

Publisher's PDF, also known as Version of record

Link to publication

Citation for pulished version (APA):

Wagner, J. (2007). Why more West than East German firms export. (Working paper series in economics; No. 42). Institut für Volkswirtschaftslehre der Universität Lüneburg.

\section{General rights}

Copyright and moral rights for the publications made accessible in the public portal are retained by the authors and/or other copyright owners and it is a condition of accessing publications that users recognise and abide by the legal requirements associated with these rights.

- Users may download and print one copy of any publication from the public portal for the purpose of private study or research.

- You may not further distribute the material or use it for any profit-making activity or commercial gain

- You may freely distribute the URL identifying the publication in the public portal ?

Take down policy

If you believe that this document breaches copyright please contact us providing details, and we will remove access to the work immediately and investigate your claim. 
Why more West than East German firms export

$$
\begin{gathered}
\text { by } \\
\text { Joachim Wagner }
\end{gathered}
$$

University of Lüneburg Working Paper Series in Economics

No. 42

March 2007

www.uni-lueneburg.de/vwl/papers

ISSN 1860 - 5508 


\title{
Why more West than East German firms export \\ Joachim Wagner
}

\author{
University of Lueneburg, Institute of Economics \\ Institute for the Study of Labor (IZA), Bonn \\ Max Planck Institute of Economics, Jena \\ wagner@uni-lueneburg.de
}

\section{Abstract:}

Using unique new data and a recently introduced non-linear decomposition technique this paper shows that the huge difference in the propensity to export between West and East German plants is to a large part due to differences in firm size and human capital intensity.

Keywords: Exports, micro data, West Germany, East Germany

\section{JEL classification: F14}

\section{Address for correspondence:}

Prof. Dr. Joachim Wagner

University of Lueneburg

Institute of Economics

PO Box 2440

D-21314 Lueneburg

Germany

Phone: +49-4131-677-2330

Fax: $\quad+49-4131-677-2026$

http://www.uni-lueneburg.de/fb2/vwl/wifo

Acknowledgement: Computations were done inside the Research Data Centre of the Statistical Office of Berlin. Many thanks to Anja Münch and Ramona Pohl for running my Stata do-files, and for carefully checking the huge log-files for violation of privacy. 


\section{Motivation}

While Germany is one of the most important exporters of manufacturing goods in the world, by far not all manufacturing firms in Germany are exporters, and there is a remarkable gap between the share of exporters in all manufacturing firms between West Germany and East Germany. While in West Germany in 200464.4 percent of manufacturing plants were exporters, fourteen years after re-unification this share was only 45.5 percent in the former communist East Germany. The reasons for this difference are not yet well understood, not least due to a lack of comprehensive micro data. Using a unique new data set and a recently introduced non-linear decomposition technique this paper contributes to the literature by investigating the share of this gap that is due to observed plant characteristics.

The rest of the paper is organised as follows: Section 2 introduces the newly available data. Section 3 reports descriptive evidence. Section 4 outlines the nonlinear decomposition technique and presents results from its application. Section 5 concludes.

\section{Data}

The empirical investigation uses data for plants taken from regular surveys by the Statistical Offices of the German federal states covering all plants from manufacturing industries that employ at least twenty persons in the local production unit or in the company that owns the unit. Participation of plants in the survey is mandated. Late in 2006 these data were matched over all federal states to form a data set that covers Germany as a whole. In this paper the most recent available data for 2004 are used.

Note that the micro level data are strictly confidential and for use inside the Statistical Office only, but not exclusive. Further information how to access the data is given in Zühlke et al. (2004). 


\section{Descriptive evidence}

As shown in table 1 the share of exporters in all manufacturing firms ${ }^{1}$ was much lower in East Germany (45.5 percent) than in West Germany (64.4 percent) in 2004. Participation of firms in export markets is linked to firm size and factor inputs. Firms from one of the most highly developed industrial countries of the world can be expected to have a comparative advantage in technology intensive products made by highly qualified workers; furthermore, firm size is expected to be positively correlated with export activities for various reasons including scale effects, a higher capacity for taking risks in larger firms, and the fixed costs character of various export related costs like retooling and redesigning products for foreign markets (see Wagner 2001).

Table 1 documents that in both parts of Germany exporters were larger, more human capital intensive, and more often from technology intensive industries than their non-exporting counterparts. ${ }^{2}$ Results for probit models show that these links, which are in line with our theoretical priors for export participation, are statistically highly significant ceteris paribus, too.

\footnotetext{
${ }^{1}$ In this paper the term firm is used to mean a local production unit, or plant.

${ }^{2}$ Human capital intensity is measured by wage per employee. Firms are classified as high-tech or medium-tech firms according to their industry affiliation, using the standard list of technology intensive industries of Germany; details are available from the author on request. All differences are statistically significant at an error level of less than one percent.
} 
Table 1: Export participation of manufacturing firms in West and East Germany, 2004

West Germany

(Share of exporters: $64.44 \%$ )

Results for probit Sample mean estimation of export participation

Estimated coefficient (p-value)

\section{East Germany}

(Share of exporters: $45.49 \%$ )

Results for probit Sample mean estimation of export participation

$$
\begin{aligned}
& \text { Estimated } \\
& \text { coefficient }
\end{aligned}
$$$$
\text { ( } p \text {-value) }
$$

\section{Exporters} Non-exporters

\begin{tabular}{|c|c|c|c|c|}
\hline $\begin{array}{l}\text { Number of } \\
\text { employees }\end{array}$ & $\begin{array}{l}0.001408 \\
(0.000)\end{array}$ & $\begin{array}{r}176.56 \\
58.72\end{array}$ & $\begin{array}{l}0.00175 \\
(0.000)\end{array}$ & $\begin{array}{c}111.85 \\
53.23\end{array}$ \\
\hline Human capital & $\begin{array}{l}0.000024 \\
(0.000)\end{array}$ & $\begin{array}{l}31,798.70 \\
26,274.75\end{array}$ & $\begin{array}{l}0.000019 \\
(0.000)\end{array}$ & $\begin{array}{l}23,415.12 \\
20,255.12\end{array}$ \\
\hline $\begin{array}{l}\text { High-tech } \\
\text { (dummy) }\end{array}$ & $\begin{array}{l}0.308 \\
(0.000)\end{array}$ & $\begin{array}{l}0.059 \\
0.029\end{array}$ & $\begin{array}{l}0.416 \\
(0.000)\end{array}$ & $\begin{array}{l}0.074 \\
0.035\end{array}$ \\
\hline $\begin{array}{l}\text { Medium-tech } \\
\text { (dummy) }\end{array}$ & $\begin{array}{l}0.431 \\
(0.000)\end{array}$ & $\begin{array}{l}0.214 \\
0.104\end{array}$ & $\begin{array}{l}0.399 \\
(0.000)\end{array}$ & $\begin{array}{l}0.215 \\
0.120\end{array}$ \\
\hline Constant & $\begin{array}{l}-0.556 \\
(0.000)\end{array}$ & & $\begin{array}{c}-0.738 \\
(0.000)\end{array}$ & \\
\hline $\begin{array}{l}\text { Number of } \\
\text { firms }\end{array}$ & 38,147 & & 9,071 & \\
\hline
\end{tabular}

Variable 


\section{A decomposition of the difference in the propensity to export in West and}

\section{East German firms}

The figures reported in table 1 reveal a number of differences between West and

East German plants regarding the size of the estimated coefficients of the probit models, and in the composition of the samples with regard to these characteristics. Therefore, the question arises to what extent the differences of export participation across space can be explained by differences in characteristics of the firms on the one hand, and by differences in the coefficients on the other hand.

To tackle this kind of question, Fairlie (2006) introduced a decomposition method based on estimates from a non-linear probit model. While a discussion of the details of this method is beyond the scope of this paper, two aspects should be mentioned: First, while the characteristics effect identified in the decomposition represents the part of the difference in export participation that is due to observed differences over the two regions in the characteristics of the firms, the residual effect not only represents the part due to different regression coefficients but captures also the proportion of the difference due to group differences in unmeasured or unobservable factors. Second, each sub-sample can be used as the reference group, and the results usually differ according to the choice of the reference group. Therefore, both variants are computed, and the results are compared.

The type of question answered here is "How high would the share of exporting firms among all manufacturing firms in East Germany have been in 2004 if the firms from the West German sample were located in East Germany, and if the characteristics of these West German firms were linked to the probability of exporting according to the coefficients estimated using the East German sample from 2004?" Results are reported in table $2 .^{3}$

\footnotetext{
${ }^{3}$ Stata 9.2 and the program fairlie.ado were used for computations.
} 
Table 2: Decomposition analysis of differences in export participation of manufacturing firms in West and East Germany, 2004

\begin{tabular}{lllll}
\hline $\begin{array}{l}\text { Reference } \\
\text { group } \\
\text { (percent } \\
\text { exporters } \\
\text { in sample) }\end{array}$ & $\begin{array}{l}\text { Comparison } \\
\text { group } \\
\text { (percent } \\
\text { exporters } \\
\text { in sample) }\end{array}$ & $\begin{array}{l}\text { Difference in } \\
\text { participation } \\
\text { (percentage } \\
\text { points) }\end{array}$ & $\begin{array}{l}\text { Characterisitcs } \\
\text { effect } \\
\text { (percentage } \\
\text { points) }\end{array}$ & $\begin{array}{l}\text { Residual } \\
\text { effect } \\
\text { (percentage } \\
\text { points) }\end{array}$ \\
\hline $\begin{array}{l}\text { West } \\
(64.44)\end{array}$ & $\begin{array}{l}\text { East } \\
(45.49)\end{array}$ & 18.96 & 8.51 & 10.45 \\
$\begin{array}{l}\text { East } \\
(45.49)\end{array}$ & $\begin{array}{l}\text { West } \\
(64.44)\end{array}$ & -18.96 & -7.71 & -11.25 \\
- & & & \\
\hline
\end{tabular}

Detailed decomposition

$\begin{array}{lll}\text { Variable } & \begin{array}{l}\text { Characteristic effect } \\ \text { (percentage points) }\end{array} & \begin{array}{l}\text { Significance level } \\ (p \text {-value })\end{array}\end{array}$

Reference group: West Germany

\begin{tabular}{lcc}
$\begin{array}{l}\text { Number of } \\
\text { employees }\end{array}$ & 1.413 & 0.000 \\
$\begin{array}{l}\text { Human } \\
\text { capital }\end{array}$ & 7.106 & 0.000 \\
$\begin{array}{l}\text { High-tech } \\
\text { (dummy) }\end{array}$ & 0.012 & 0.005 \\
$\begin{array}{l}\text { Medium-tech } \\
\text { (dummy) }\end{array}$ & -0.034 & 0.000 \\
$\begin{array}{l}\text { Reference group: East Germany } \\
\text { Number of } \\
\text { employees }\end{array}$ & -1.678 & 0.000 \\
$\begin{array}{l}\text { Human } \\
\text { capital }\end{array}$ & -5.633 & 0.000 \\
$\begin{array}{l}\text { High-tech } \\
\text { (dummy) }\end{array}$ & 0.013 & 0.218 \\
$\begin{array}{l}\text { Medium-tech } \\
\text { (dummy) }\end{array}$ & -0.405 & 0.000 \\
\hline
\end{tabular}


When West German firms are used as the reference group, 45 percent of the difference in the export participation rate is allocated to observed firm characteristics included in the probit regression. This part is slightly lower (about 40 percent) when the reference group is formed by East German firms. The detailed decomposition shows that the lion's share of this characteristics effect is due to the much lower human capital intensity of East German plants, and that the larger average size of West German plants matters, too. The point estimates for the two technology group dummy variables are tiny (and not always statistically significant at a usual level), and for each reference group one of the coefficients has the "wrong" sign; differences in technology intensity - at least when (due to a lack of better information) measured by average R\&D intensities at the industry level - between East and West Germany do not contribute to the explanation of the huge difference in the export participation rate.

\section{Conclusions}

According to the results from a new unique data set and a recently introduced nonlinear decomposition technique, between 40 and 45 percent of the large difference in the share of exporting firms in West and East Germany can be explained by the higher human capital intensity and - to a less degree - by the larger average size of West German firms. On the one hand, this is an important result that helps to understand why this difference is still that large one decade and a half after reunification. On the other hand, the residual effect - which is at least in part a measure of our ignorance - is more than 50 percent, and this points to the need of further research based on more informative plant level data that will hopefully allow the inclusion of more plant characteristics in the decomposition. 


\section{References}

Fairlie, R. W. (2006): An Extension of the Oaxaca-Blinder Decomposition Technique to Logit and Probit Models. Institute for the Study of Labor, IZA Discussion Paper No. 1917, Bonn, January.

Wagner, Joachim. 2001. "A Note on the Firm Size - Export Relationship." Small Business Economics 17, 229-237.

Zühlke, Sylvia et al. 2004. "The Research Data Centres of the Federal Statistical Office and the Statistical Offices of the Länder." Schmollers Jahrbuch / Journal of Applied Social Science Studies 124(4), 567-578. 


\section{Working Paper Series in Economics}

(see www.uni-lueneburg.de/vwl/papers for a complete list)

No.41: Joachim Wagner: Exports and Productivity in Germany, March 2007

No.40: Lena Koller, Klaus Schnabel und Joachim Wagner: Schwellenwerte im Arbeitsrecht. Höhere Transparenz und Effizienz durch Vereinheitlichung, Februar 2007 [erscheint in: Perspektiven der Wirtschaftspolitik]

No.39: $\quad$ Thomas Wein und Wiebke B. Röber: Sind ausbildende Handwerksbetriebe erfolgreicher?, Januar 2007

No.38: Joachim Wagner: Institut für Volkswirtschaft: Forschungsbericht 2006, Januar 2007

No.37: Nils Braakmann: The impact of September $11^{\text {th }}, 2001$ on the job prospects of foreigners with Arab background - Evidence from German labor market data, January 2007

No.36: Jens Korunig: Regulierung des Netzmonopolisten durch Peak-load Pricing?, Dezember 2006

No.35: Nils Braakmann: Die Einführung der fachkundigen Stellungnahme bei der Ich-AG, November 2006

No.34: Martin F. Quaas and Stefan Baumgärtner: Natural vs. financial insurance in the management of public-good ecosystems, October 2006

No.33: $\quad$ Stefan Baumgärtner and Martin F. Quaas: The Private and Public Insurance Value of Conservative Biodiversity Management, October 2006

No.32: Ingrid Ott and Christian Papilloud: Converging institutions. Shaping the relationships between nanotechnologies, economy and society, October 2006

No.31: Claus Schnabel and Joachim Wagner: The persistent decline in unionization in western and eastern Germany, 1980-2004: What can we learn from a decomposition analysis?, October 2006

No.30: Ingrid Ott and Susanne Soretz: Regional growth strategies: fiscal versus institutional governmental policies, September 2006

No.29: $\quad$ Christian Growitsch and Heike Wetzel: Economies of Scope in European Railways: An Efficiency Analysis, July 2006

No.28: Thorsten Schank, Claus Schnabel and Joachim Wagner: Do exporters really pay higher wages? First evidence from German linked employer-employee data, June 2006 [forthcoming in: Journal of International Economics]

No.27: Joachim Wagner: Markteintritte, Marktaustritte und Produktivität Empirische Befunde zur Dynamik in der Industrie, März 2006

No.26: Ingrid Ott and Susanne Soretz: Governmental activity and private capital adjustment, March 2006

[forthcoming in: Icfai Journal of Managerial Economics]

No.25: Joachim Wagner: International Firm Activities and Innovation: Evidence from Knowledge Production Functions for German Firms, March 2006

No.24: $\quad$ Ingrid Ott und Susanne Soretz: Nachhaltige Entwicklung durch endogene Umweltwahrnehmung, März 2006

No.23: John T. Addison, Claus Schnabel, and Joachim Wagner: The (Parlous) State of German Unions, February 2006

[forthcoming in: Journal of Labor Research] 
No.22: Joachim Wagner, Thorsten Schank, Claus Schnabel, and John T. Addison: Works Councils, Labor Productivity and Plant Heterogeneity: First Evidence from Quantile Regressions, February 2006

[published in: Jahrbücher für Nationalökonomie und Statistik 226 (2006), 505 - 518]

No.21: Corinna Bunk: Betriebliche Mitbestimmung vier Jahre nach der Reform des BetrVG: Ergebnisse der 2. Befragung der Mitglieder des Arbeitgeberverbandes Lüneburg Nordostniedersachsen, Februar 2006

No.20: Jan Kranich: The Strength of Vertical Linkages, July 2006

No.19: Jan Kranich und Ingrid Ott: Geographische Restrukturierung internationaler Wertschöpfungsketten - Standortentscheidungen von KMU aus regionalökonomischer Perspektive, Februar 2006

No.18: $\quad$ Thomas Wein und Wiebke B. Röber: Handwerksreform 2004 - Rückwirkungen auf das Ausbildungsverhalten Lüneburger Handwerksbetriebe?, Februar 2006

No.17: Wiebke B. Röber und Thomas Wein: Mehr Wettbewerb im Handwerk durch die Handwerksreform?, Februar 2006

No.16: Joachim Wagner: Politikrelevante Folgerungen aus Analysen mit wirtschaftsstatistischen Einzeldaten der Amtlichen Statistik, Februar 2006 [publiziert in: Schmollers Jahrbuch 126 (2006) 359-374]

No.15: Joachim Wagner: Firmenalter und Firmenperformance Empirische Befunde zu Unterschieden zwischen jungen und alten Firmen in Deutschland, September 2005 [publiziert in: Lutz Bellmann und Joachim Wagner (Hrsg.), Betriebsdemographie (Beiträge zur Arbeitsmarkt- und Berufsforschung, Band 305), Nürnberg: IAB der BA, 83-111]

No.14: Joachim Wagner: German Works Councils and Productivity: First Evidence from a Nonparametric Test, September 2005 [forthcoming in: Applied Economics Letters]

No.13: Lena Koller, Claus Schnabel und Joachim Wagner: Arbeitsrechtliche Schwellenwerte und betriebliche Arbeitsplatzdynamik: Eine empirische Untersuchung am Beispiel des Schwerbehindertengesetzes, August 2005

[publiziert in: Zeitschrift für ArbeitsmarktForschung/ Journal for Labour Market Research 39 (2006), 181-199]

No.12: Claus Schnabel and Joachim Wagner: Who are the workers who never joined a union? Empirical evidence from Germany, July 2005 [published in: Industrielle Beziehungen/ The German Journal of Industrial Relations 13 (2006), 118-131]

No.11: Joachim Wagner: Exporte und Produktivität in mittelständischen Betrieben Befunde aus der niedersächsischen Industrie (1995 - 2004), June 2005 [publiziert in: Niedersächsisches Landesamt für Statistik, Statistische Berichte Niedersachsen, Sonderausgabe: Tagung der NLS am 9. März 2006, Globalisierung und regionale Wirtschaftsentwicklung - Datenlage und Datenbedarf in Niedersachsen. Hannover, Niedersächsisches Landesamt für Statistik, Juli 2006, 18 - 29] 
No.10: Joachim Wagner: Der Noth gehorchend, nicht dem eignen Trieb.

Nascent Necessity and Opportunity Entrepreneurs in Germany.

Evidence from the Regional Entrepreneurship Monitor (REM), May 2005

[published in: RWI: Mitteilungen. Quarterly 54/ 55 (2003/04), 287-303

\{published June 2006\}]

No. 9: Gabriel Desgranges and Maik Heinemann: Strongly Rational Expectations Equilibria with Endogenous Acquisition of Information, March 2005

No. 8: Joachim Wagner: Exports, Foreign Direct Investment, and Productivity: Evidence from German Firm Level Data, March 2005

[published in: Applied Economics Letters 13 (2006), 347-349]

No. 7: $\quad$ Thomas Wein: Associations' Agreement and the Interest of the Network Suppliers - The Strategic Use of Structural Features, March 2005

No. 6: Christiane Clemens and Maik Heinemann: On the Effects of Redistribution on Growth and Entrepreneurial Risk-Taking, March 2005

No. 5: Christiane Clemens and Maik Heinemann: Endogenous Redistributive Cycles - An overlapping Generations Approach to Social Conflict and Cyclical Growth, March 2005

No. 4: Joachim Wagner: Exports and Productivity: A Survey of the Evidence from Firm Level Data, March 2005

[published in: The World Economy 30 (2007), 1, 60-82]

No. 3: $\quad$ Thomas Wein and Reimund Schwarze: Is the Market Classification of Risk Always Efficient? - Evidence from German Third Party Motor Insurance, March 2005

No. 2: Ingrid Ott and Stephen J. Turnovsky: Excludable and Non-Excludable Public Inputs: Consequences for Economic Growth, June 2005 (Revised version) [published in: Economica 73 (2006), 292, 725-742 also published as CESifo Working Paper 1423]

No. 1: Joachim Wagner: Nascent and Infant Entrepreneurs in Germany. Evidence from the Regional Entrepreneurship Monitor (REM), March 2005 [published in: Simon C. Parker (Ed.), The Life Cycle of Entrepreneurial Ventures (International Handbook Series on Entrepreneurship, Volume 3), New York etc.: Springer, 2006, 15-37] 
Universität Lüneburg

Institut für Volkswirtschaftslehre

Postfach 2440

D-21314 Lüneburg

Tel.: ++49 41316772321

email: brodt@uni-lueneburg,de

www.uni-lueneburg.de/vwl/papers 